
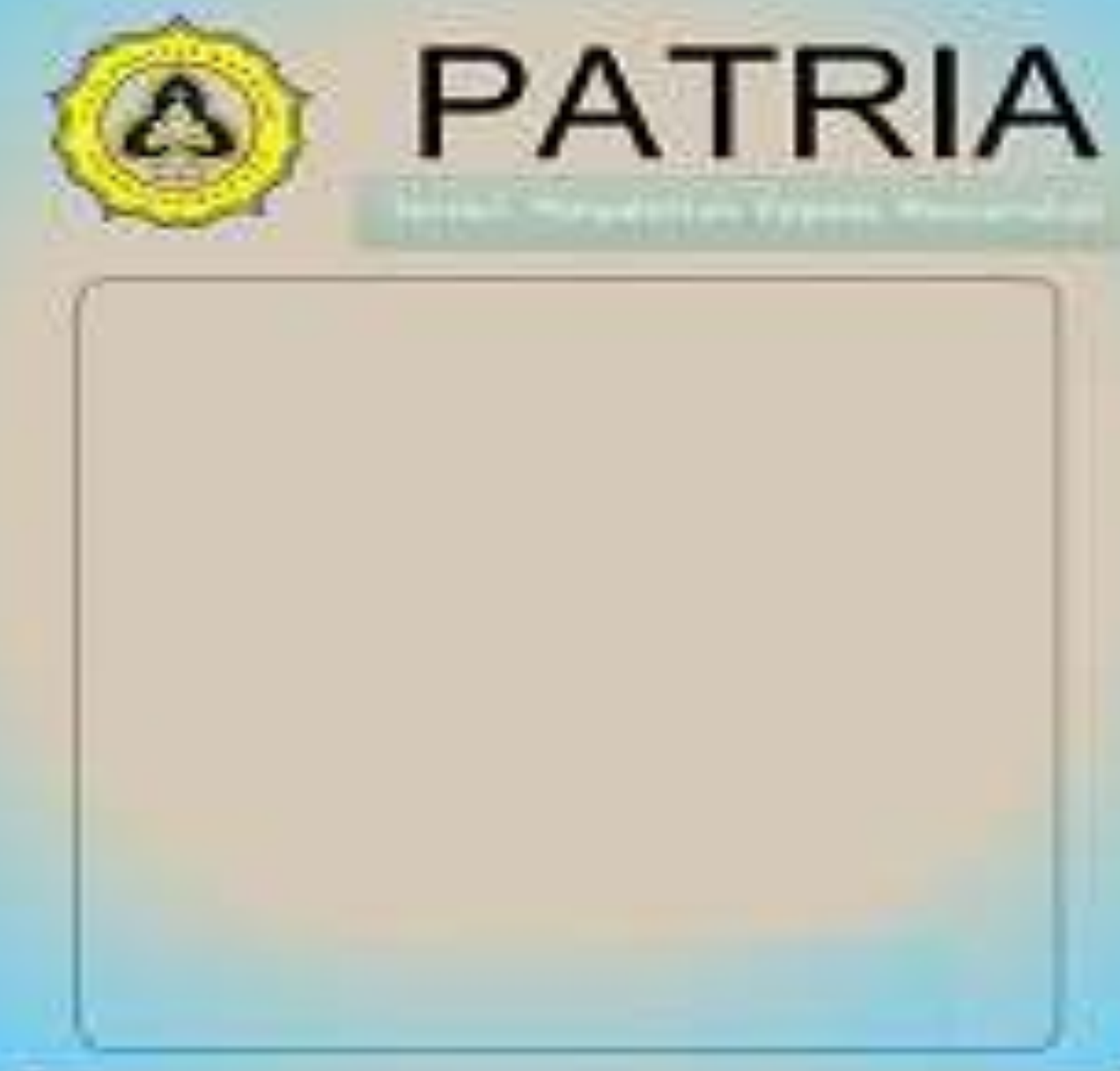

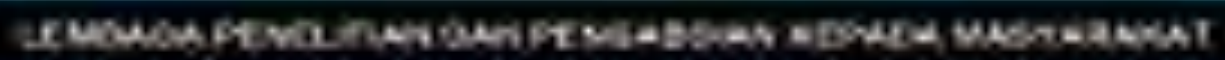




\section{( $)$ PATRIA}

Jurnal Pengabdlian Pada Masyarakat

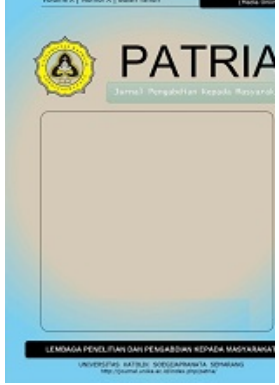

ABOUT THE JOURNAL

E-ISSN

Focus and Scope

Peer Review Process

Publication Ethics

Statement

Open Access Policy

Author Guidelines

Editorial Team

Peer-Reviewer

Contact

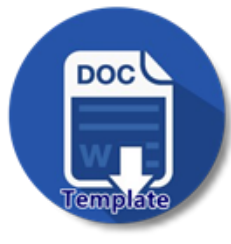

statcounte

grammarly

PLAGIARISM

CHECK.ORG

\section{8.? MENDELE}

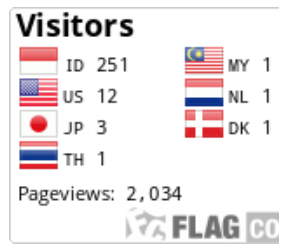

\section{Editorial Team}

\section{Chief Editor}

Dr. Berta Bekti Retnawati, MSi, Magister Management, Soegijapranata Catholic

University, Indonesia

\section{Editor}

Hironimus Leong, S.Kom, M.Kom, Program Studi Teknik Informatika Universitas Katolik Soegijapranata, Indonesia

Dr. I Putu Sugiartha Sanjaya, SE., M. Si., Ak., CA, Universitas Atma Jaya Yogyakarta, Indonesia

Dr. Rio Dhani Laksana, M.Sc, Program Studi Manajemen, Universitas Jenderal Soedirman, Purwokerto

Dr.E. Drs. Marno Nugroho, MM, Universitas Islam Sultan Agung Semarang Dr. E. Hartaty Hadady, SE., M.Si, Universitas Khairun, Ternate Maluku Utara

506 View My Stats | ISSN 2656-5455 (media online)
UREIN JUUKINAL DY DIEIVIS

INFORMATION

For Readers

For Authors

For Librarians

USER

Username

Password

$\square$ Remember me

Login

NOTIFICATIONS

View

Subscribe

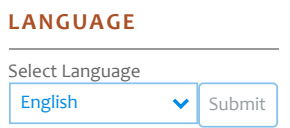

JOURNAL CONTENT

Search

All

Search

Browse

By Issue

By Author

By Title

Other Journals

Categories

VISITOR NUMBER :

831533

View My Stats

SEARCH RESOURCES

Search

Library

Search 


\section{( $)$ PATRIA}

Jurnal Pengabdlian Pada Masyarakat

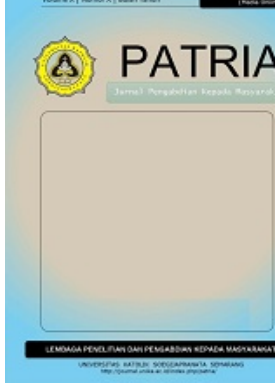

ABOUT THE JOURNAL

E-ISSN

Focus and Scope

Peer Review Process

Publication Ethics

Statement

Open Access Policy

Author Guidelines

Editorial Team

Peer-Reviewer

Contact

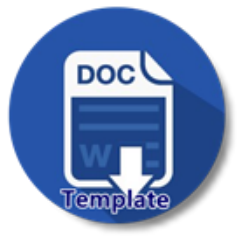

statcounte

grammarly

PLAGIARISM

CHECK.ORG

\section{8.? MENDELE}

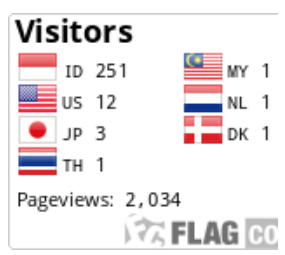

\section{People}

\section{Reviewer}

Dr. Dra. Ekawati Marhaenny Dukut, M.Hum., Faculty of Language \& Arts, Soegijapranata Catholic University

Anton Agus Setyawan, Fak Ekonomi Dan Bisnis Univ Muhammadiyah Surakarta

Dra. Cecillia Cecilia Titiek Murniati, M.A., Ph., English Dept. Fac. of Language \& Arts, Soegijapranata Catholic University, Semarang, Indonesia

Prof. Dr. Ni Nyoman Kerti Yasa, SE., MS., Fakultas Ekonomi dan Bisnis Universitas Udayana, Denpasar, Indonesia

DR. Siti Zulaikha Wulandari, Universitas Jenderal Soedirman Purwokerto

Prof. Dr. Naili Farida, MSi, Universitas Diponegoro Semarang

Dr. Robiyanto , SE, MM, Universitas Kristen Satya Wacana Salatiga

Dr. Nuryakin, SE., MM, Universitas Muhammadiyah Yogyakarta

Dr. Hendar, SE, M.Si, Univeristas Islam Sultan Agung Semarang

Dr. Hersugondo, SE., MM, Universitas Diponegoro Semarang

Ir. Resmana Lim, M.Eng, Universitas Kristen Petra, Surabaya, Indonesia

Dr. Florentinus Budi Setiawan, Univeristas Katolik Soegijapranata, Semarang

Dr. Heny Hartono, SS, M.Pd, English Dept. Fac. of Language \& Arts, Soegijapranata Catholic University, Semarang, Indonesia

Dr. Rr. M. I. Retno Susilorini, Scopus ID: 56527219900, Soegijapranata Catholic University, Indonesia

Dr. Ir. Bernadeta Soedarini, MP, Fakultas Teknologi Pertanian Universitas Katolik Soegijapranata, Semarang, Indonesia

Dra. Lucia Hernawati, M.S., Fakultas Psikologi Unika Soegijapranata, Indonesia

Ch. Tri Harjanti Nugrahaningsih, SE, MSi, Fakultas Ekonomi dan Bisnis Universitas Katolik Soegijapranata, Semarang, Indonesia

Mr YB Dwi Setianto, Soegijapranata Catholic University, Indonesia
UREIV JUUKINAL DYSIEIVIS

INFORMATION

For Readers

For Authors

For Librarians

USER

Username $\square$

$\square$ Remember me

Login

NOTIFICATIONS

View

Subscribe

\begin{tabular}{l} 
LANGUAGE \\
\hline Select Language \\
\begin{tabular}{llll}
\hline English & & \\
\end{tabular}
\end{tabular}

JOURNAL CONTENT

Search

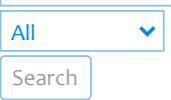

Browse

By Issue

By Author

By Title

Other Journals

Categories

VISITOR NUMBER :

831540

View My Stats

SEARCH RESOURCES

Search

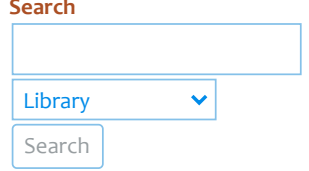




\section{( $)$ PATRIA}

Jurnal Pengabdlian Pada Masyarakat

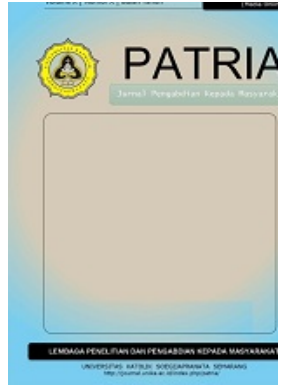

ABOUT THE JOURNAL

E-ISSN

Focus and Scope

Peer Review Process

Publication Ethics

Statement

Open Access Policy

Author Guidelines

Editorial Team

Peer-Reviewer

Contact

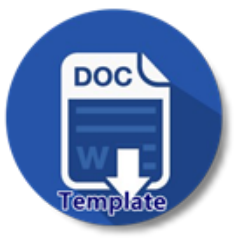

statcounte

grammarly

PLAGIARISM

CHECK.ORG

\section{คిํ MENDELE}

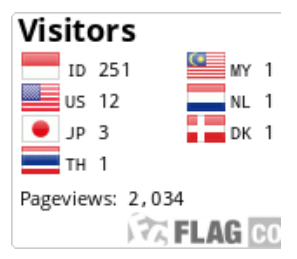

Vol 2, No 1

Maret 2020

DOI: https://doi.org/10.24167/patria.v2i1

\section{Table of Contents}

\section{Articles}

Pembentukan Kelompok Asuhan Mandiri Tanaman Obat Keluarga (TOGA) dan Akupresur di Kecamatan Sanden,

Kabupaten Bantul

DOI 10.24167/patria.v2i1.2569

Suryani Hutomo, Yanti Ivana Suryanto, Novika

Kurniawati

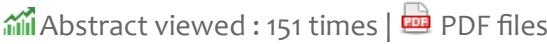

downloaded : 16 times

Analisis Pemetaan Profil Badan Usaha Milik Desa Serta Potensi dan Permasalahannya di Bidang Pengelolaan Air Bersih: (studi kasus di BUMDes Kertajaya, Cianjur, Provinsi Jawa Barat)

DOI 10.24167/patria.v2i1.2570

Hanny Hanny, Lidya Agustina, Ita Salsalina Lingga, Rapina Rapina, Yenni Carolina, Elyzabeth I Marpaung, Erna Erna, Herman Kambono, Lauw Tjun Tjun,

Oktavianti Oktavianti, Enrico Goiyardi

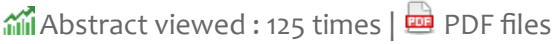

downloaded : 10 times

\section{Pendidikan Antikorupsi Kepada Siswa Sekolah Dasar}

Dengan Metode Storytelling

DOI 10.24167/patria.v2i1.2584

Naurissa Biasini, Clara Moningka, Emma R Aliudin, Suci Marini

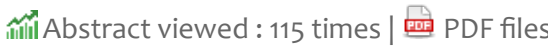

downloaded : 6 times

Penataan Kawasan Wisata Curug Banyu Nibo Desa Sendangsari Kecamatan Pajangan Kabupaten Bantul Daerah Istimewa Yogyakarta

DOI 10.24167/patria.v2i1.2585

Amos Setiadi, Lucia Asdra Rudwiarti

而而 Abstract viewed : 79 times | ․ㅣㅁ PDF files downloaded

: 6 times

Upaya Peningkatan Pemahaman Terhadap Bahaya Sampah Plastik Dan Pengolahannya Bagi Siswa-Siswi SMA Negeri 3 Kota Kupang, Nusa Tenggara Timur DOI 10.24167/patria.v2i1.2586
UREIN JUUKINAL DY DIEIVIS

INFORMATION

For Readers

For Authors

For Librarians

USER

Username $\square$

$1-7$

$\square$ Remember me

Login

NOTIFICATIONS

View

Subscribe

PDF

$8-24$

LANGUAGE

Select Language English $\checkmark$ Submit

JOURNAL CONTENT

Search

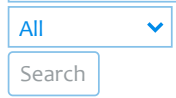

Browse

PDF

$25-34$

By Issue

By Author

By Title

Other Journals

Categories

VISITOR NUMBER :

\section{5}

View My Stats

SEARCH RESOURCES

Search

Library

Search 
Anselmus Boy Baunsele, Christiani Dewi Q. M. Bulin, Hildegardis Missa

筱Abstract viewed : 103 times | 밀 PDF files

downloaded : 8 times

Sistem Informasi Geografis Pemetaan Sungai dan

Bangunan Utama pada Daerah Irigasi Kewenangan

Provinsi di Pulau Timor

DOI 10.24167/patria.v2i1.2587

Christiani Chandra Manubulu, Frederikus D. Ndouk

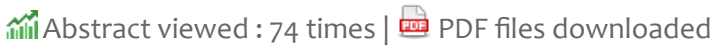

: 6 times

Pendampingan Penerapan Sistem Informasi pada Pos

DOI 10.24167/patria.v2i1.2588

Kristian Adi Nugraha, Danny Sebastian, Maria Nila

Anggia Rini

䔣 Abstract viewed : 120 times | PDF files

downloaded : 15 times

Penguatan Desa Wisata Berbasis Kampung Iklim:

Menuju Terwujudnya Ketahanan Pangan di Desa

Pandowoharjo Sleman Yogyakarta

DOI 10.24167/patria.v2i1.2589

B. Tresno Sumbodo, Sardi Sardi, Sunarya Sunarya,

Hermawan Prasetyanto

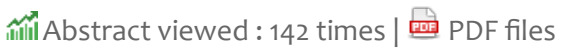

downloaded : 16 times

506 View My Stats | ISSN 2656-5455 (media online) 


\title{
Penataan Kawasan Wisata Curug Banyu Nibo Desa Sendangsari Kecamatan Pajangan Kabupaten Bantul Daerah Istimewa Yogyakarta
}

\author{
Amos Setiadi $^{\# 1}$, Lucia Asdra Rudwiarti ${ }^{* 2}$ \\ ${ }^{1}$ amos.setiadi@uajy.ac.id \\ 3lucia.asdra@uajy.ac.id \\ Program Studi Magister Arsitektur Universitas Atma Jaya Yogyakarta
}

\begin{abstract}
"Pengabdian pada Masyarakat" (Abdimas) of Curug Banyu Nibo was done to assist partner by designing tourism supporting facilities. The intended outcomes of this Abdimasare the increase of tourist visits and its effect on the welfare of the surrounding local communities. The Abdimas was conducted in three steps, i.e. Preparation and Data Collection; Location Survey and InterviewingPartners; Drafting Concepts and Designs. The conclusion of the program is a design of tourism supporting facilities in Curug Banyu Nibo such as gate, joglo, parks, pathways, gazebos, and culinary stalls.
\end{abstract}

Keywords-Tourism, Facilities, Tourist, Curug Banyu Nibo, Welfare,

\section{PENDAHULUAN}

Kawasan Wisata Curug Banyu Nibo yaitu kawasan wisata alam yang berada di puncak bukit di Desa Sendangsari Kecamatan Pajangan Kabupaten Bantul, yang memiliki potensi wisata pemandangan alam. Perancangan Master Plan Kawasan Wisata ini merupakan kegiatan Pengabdian pada Masyarakat (Abdimas) dilakukan dengan bekerjasama dengan BAPPEDA Kabupaten Bantul dan Kantor Desa Sendangsari. Dalam penentuan lokasi Abdimas, tidak lepas dari arahan dan masukan dari Bidang Pengendalian Penelitian dan Pengembangan BAPPEDA Kabupaten Bantul, supaya ada sinkronisasi antara program Pemerintah dan Abdimas. Kawasan Wisata Curug Banyu Nibomerupakan wisata alam yang berada di area perbukitan dan menawarkan potensi wisata view yang ada disekitarnya. Kawasan Wisata Curug Banyu Nibo merupakan wisata desa yang dikelola oleh masyarakat desa Sendangsari dan dipimpin oleh penasehat wisata dari kantor desa. Kawasan Wisata Curug Banyu Nibo memiliki objek Air Terjun, Mata Air, panorama dan menawarkan wisata pemandangan yang indah dari atas bukit. Dalam mendukung objek wisata ini masyarakat desa Sendangsari membuat inovasi fasilitas sementaranamun secara arsitektural masih belum menarik. Selain itu karangtaruna setempat juga telah membuat infrastruktur sederhana pendukung pariwisata seperti toilet, warung, gazebo dan tempat sampah.

Sebagai objek wisata, kawasan Curug Banyu Nibo diharapkan akan memberi kontribusi perekonomian dan meningkatkan kesejahteraan masyarakat, meningkatkan kualitas hidup dan meningkatkan fasilitas bagi wisatawan[1]. Namun demikian, kegiatan wisata perlu ditopang oleh pelaku usaha jasa pendukung lainnya (transportasi, penginapan, rumah makan, dan industri perlengkapan wisata lainnya)[2]. 


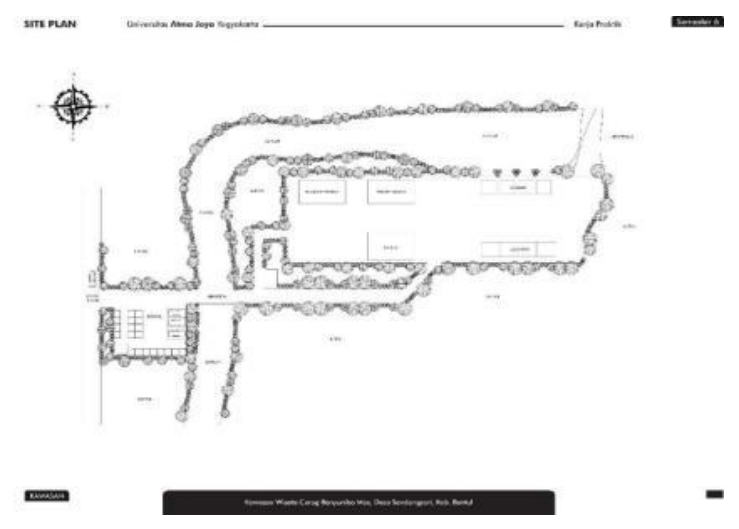

Gambar 1. Site PlanCurug Banyu Nibo. Sumber: digambar oleh AkbarF Nugroho (2019)

Kawasan Wisata Curug Banyu Nibo berada di dusun Kabrokan KulonD esa Sendangsari, yang memiliki potensi pemandangan alam. Kawasan Curug Banyu Nibo berada di Desa Sendangsari, Kecamatan Pajangan, Bantul, Daerah Istimewa Yogyakarta dengan luas dusun +49ha[3]. Kondisi tanah berkontur, semakin menuju air terjun kontur semakin tinggi. Program yang sudah dilaksanakan antara lain:

a. Pembentukan Pokdarwis Banyunibo

b. Sosialisasi kepada masyarakat (Dusun

Kabrokan Kulon dan dusun terdekat) tentang potensi wisata di Dusun Kabrokan Kulon.

c. Pembangunan WC Umum di lokasi Curug Banyu Nibo

d. Pengadaan tempat/bak sampah

e. Pembangunan Gazebo

f. Pembangunan tempat duduk di sekitar lokasi Curug Banyu Nibo

g. Pembangunan jembatan untuk akses masuk menuju lokasi Curug Banyu Nibo

h. Pembangunan tempat ibadah di lokasi Curug BanyuNibo

i. Pengadaan event sebagai salah satu media promosi

j. Membuat paket wisata dan promosi melalui website dan leaflet.

k. Kerja bakti setiap hari minggu

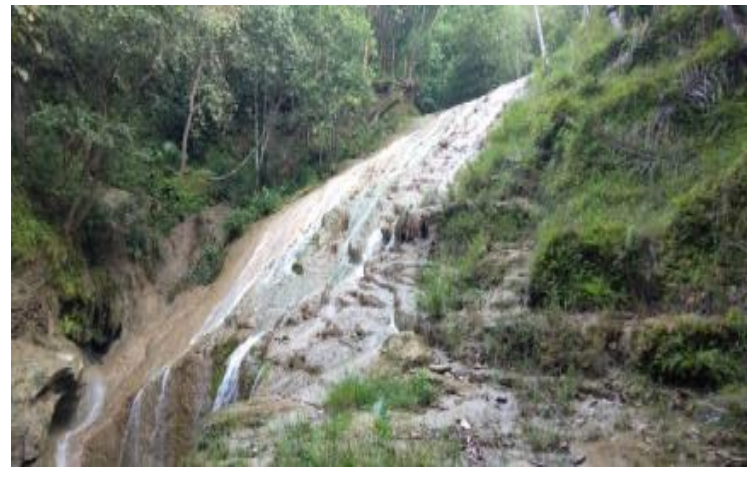

Gambar 2. Air Terjun. Sumber: Foto oleh Akbar (2019)

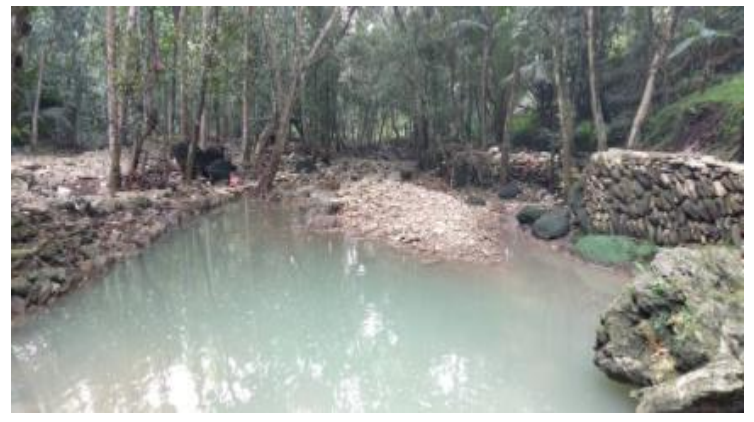

Gambar 3. Mata Air. Sumber: Foto oleh Akbar (2019)

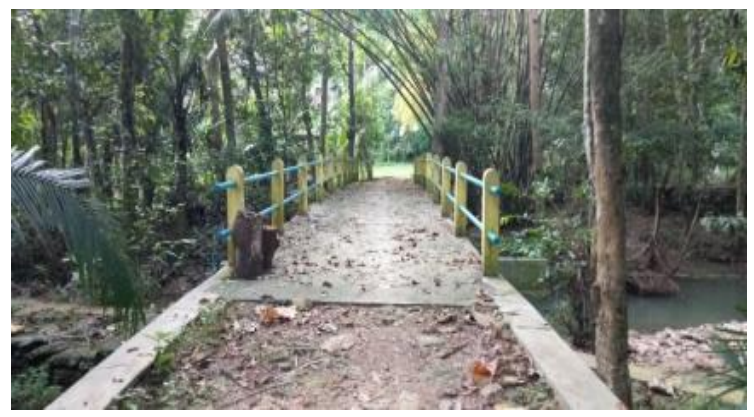

Gambar 4. Jalan menuju lokasi. Sumber: Foto oleh Akbar (2019)

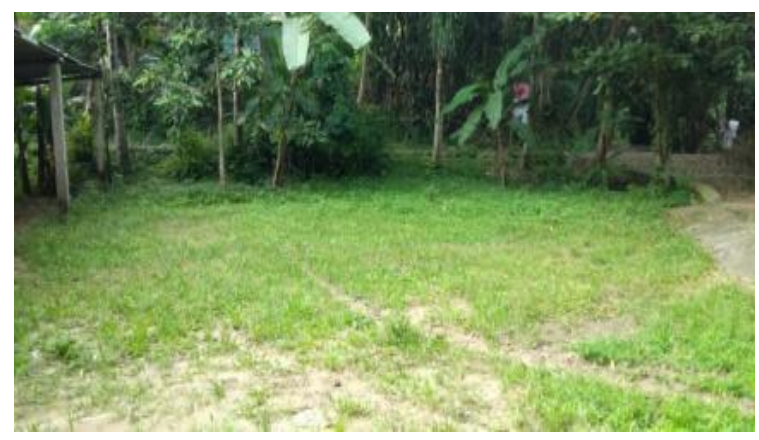

Gambar 5. Fasilitas sementara (Parkir). Sumber: Foto oleh Akbar (2019) 


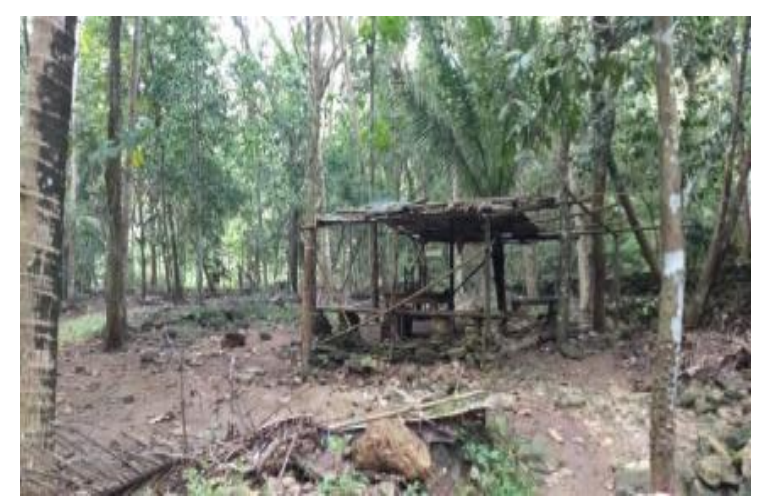

Gambar 6. Fasilitas sementara (Warung).

Sumber: Foto oleh Akbar (2019)

Kawasan wisata Curug Banyu Nibo memiliki embrio wisata air terjun, namun fasilitas pendukung wisata di kawasan Curug Banyu Nibobelum pernah dirancang sehingga belum berkembang. Fasilitas pendukung kawasan wisata merupakan elemenpenting pembangunan kawasan wisata, karena selain pendukung kawasan juga berfungsi sebagai wadah berkegiatan wisatawan selama berada di objek wisata. Masalah pada kegiatan Abdimas ini dengan mempertimbangkan masukan dari masyarakat, yaitu: bagaimana wujud disain Master plan kawasan wisata Curug Banyu Nibo yang mempetimbangkan konteks alam setempat?

Berdasarkan masalah tersebut, Abdimas ini bertujuan membuat disain Master plan kawasan dan fasilitas pendukung wisata untuk mengoptimalkan potensi yang ada agar mampu mewadahi kegiatan wisatawan dan pada akhirnya akan meningkatkan kesejahteraan masyarakat pelaku wisata di tempat tersebut.
Abdimasini
dilaksanakan bekerjasama dengan Bidang Pengendalian, Penelitian dan Pengembangan BAPPEDA Kabupaten Bantul, supaya ada sinkronisasi antara program Pemerintah.

\section{TINJAUAN WISATA ALAM}

\section{Pengertian}

Pariwisata yaitu kegiatan wisata yang didukung berbagai fasilitas serta layanan yang disediakan oleh masyarakat, pengusaha, pemerintah, dan pemerintah daerah, sebagaimana dinyatakan dalam Undang-Undang RI Nomor 10 Tahun 2009 tentang kepariwisataan, [4]. Pariwisata adalah kegiatan pemerintah, dunia usaha dan masyarakat dalam mengatur, mengurus dan melayani wisatawan. Obyek wisata alam adalah alam beserta ekosistem baik asli maupun setelah ada perpaduan dengan daya cipta manusia, yang mempunyai daya tarik untuk dilihat dan dikunjungi wisatawan[5].

Menurut Pasal 31 Undang-undang No.5 tahun 1990 tentang Konservasi sumber daya alam hayati dan ekosistemnya menyebutkan bahwa dalam taman wisata alam dapat dilakukan kegiatan untuk kepentingan penelitian, ilmu pengetahuan, pendidikan, menunjang budidaya dan wisata alam. Maka taman wisata alam adalah kawasan pelestarian alam yang dimanfaatkan sebaagai pariwisata dan rekreasi alam[6].

\section{METODOLOGI}

Penataan Kawasan Curug Banyu Nibo ini dilaksanakan dengan tahapan dan metode sebagai berikut:

1. Persiapan meliputi penyusunan rencana kegiatan

2. Pengumpulan data baikdata primer dan data sekunder, melalui: Observasi di lapangan, mengukur tapak, dokumentasi, dan wawancara.

3. Studi literatur tentang konsep perancangan tapak, area wisata alam, regulasi tata ruang di Kabupaten Bantul.

4. Analisis data deskriptif kualitatif

5. Konsep dan rancangan Master Plan 


\section{HASIL DAN PEMBAHASAN}

Berdasarkan Dokumen Tata Ruang Wilayah (RDTR) Kecamatan Pajangan, kawasan wisata Curug Banyu Nibo termasuk kawasan wisata alam ilmu pengetahuan dan budaya, yang berfungsi sebagai kawasan pariwisata, pertanian dan perkebunan[7].

Analisis SWOT kawasan Curug Banyu Nibo sebagai berikut:

a. Kekuatan:

- S1: Memiliki kekuatan sebagai tempat yang masih alami dan view pemandangan alam.

- S2: Memiliki kekuatansebagai tempat yang nyaman untuk rekreasi.

b. Kelemahan:

- W1: Masih minimnya fasilitas pendukung yang ada.

- W2: Masih belum dibuat spot-spot foto untuk pengunjung .

- W3: Belum ada Pengelola dari pihak c. Peluang: Kecamatan Pajangan

- O1: Masyarakat (wisatawan) yang menyukai tempat baru terutama pada obyek yang memiliki spot foto dan pemandangan alam yang bagus di Bantul meningkat.

- O2: Meningkatnya ketertarikan pengunjung terhadap objek wisataalam di Bantul.

d. Tantangan

- T1: Akses jalan menuju masih kurang baik (belum diaspal).

- T2: Kurangnya tata tanda (street furniture) jalan menuju obyek wisata Strategi SWOT Curug Banyu Nibo

$\mathrm{SO}_{1}$ : Mempromosikan melalui berbagai media.

$\mathrm{SO}_{2}$ : Melakukan penambahan fasilitas dan spot-spot foto.

$\mathrm{ST}_{1}$ : Melakukan perbaikan jalan menuju kawasan.

ST2 : Menambah tata tandadan penunjuk arah
$\mathrm{WO}_{1}$ : Meningkatkan fasilitas umum.

$\mathrm{WO}_{2}$ : Warga dapat menyediakan kulinerbagi pengunjung.

$\mathrm{WT}_{1}$ : Meningkatkan fasilitas warung makan,

$\mathrm{WT}_{2}$ : Melakukan pelibatan warga desa

Analisis penataan kawasan Curug Banyu Nibo mempertimbangkan lokasinya yang berciri pertanian dan perkebunan, serta pedesaan. Site Plan kawasan Curug Banyu Nibo berdasarkan analisis tapak, sebagai berikut: Pengolahan tata massa bangunan menyesuaikan dengan eksistensi air terjun. Akses utama terletak pada sisi Timur tapak yang menuju Puncak dari penghubung ke jalan utama desa menuju bagian atas Puncak Sosok. Area bagian atas merupakan area untuk menikmati keindahan matahari terbenam (sunset), pemandangan alam serta jalur sepeda gunung (downhill tracking) yang dapat diamati dari pagi hingga malam hari pada saat langit cerah.

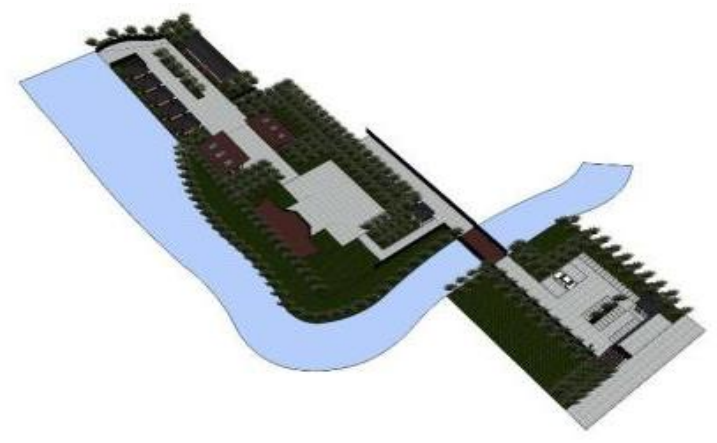

Gambar 7. Site Plan Kawasan. Sumber: Gambar oleh Akbar (2019)

Pengolahan sitemengikutitopografi lahan, serta orientasi fasilitas pendukung kenyamanan wisatawan terhadap eksistensi air terjun. Penataan ruang mempertimbangkan kualitas positif pemandangan air terjun dan tutupan vegetasi di sekitar air terjun sebagai fokus titik pandang. Sesuai Pergub no.1/2017 tentang arsitektur bangunan berciri daerah maka konsep bentuk fasilitas pendukung 
wisata Curug Banyu Nibo mengacu pada arsitektur tradisional Yogyakarta.

\section{A. Gerbang dan Akses Masuk Kawasan}

Bentuk gerbang masuk kawasan mengambil tema bambu dipadukan dengan material batu kali danbatu bata. Berdasarkan masukan dari pihak desa, ornamen diambil dari kraton Yogyakartayang memiliki makna memelihara kehidupan bermasyarakat yang lebih baik [8]. Pemilihan warna coklat, merah, hijau mengadopsi konsep tradisional.

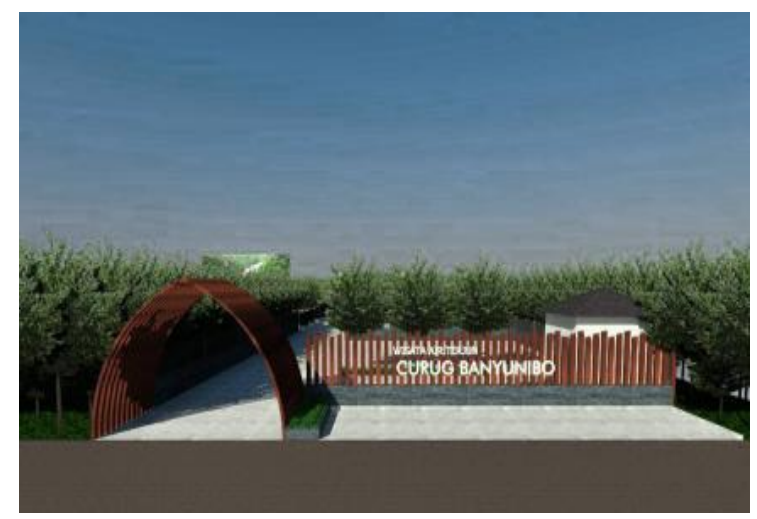

Gambar 8. Konsep bentuk gerbang masuk kawaan mengadopsi material bambu .Sumber: Gambar oleh Akbar (2019)

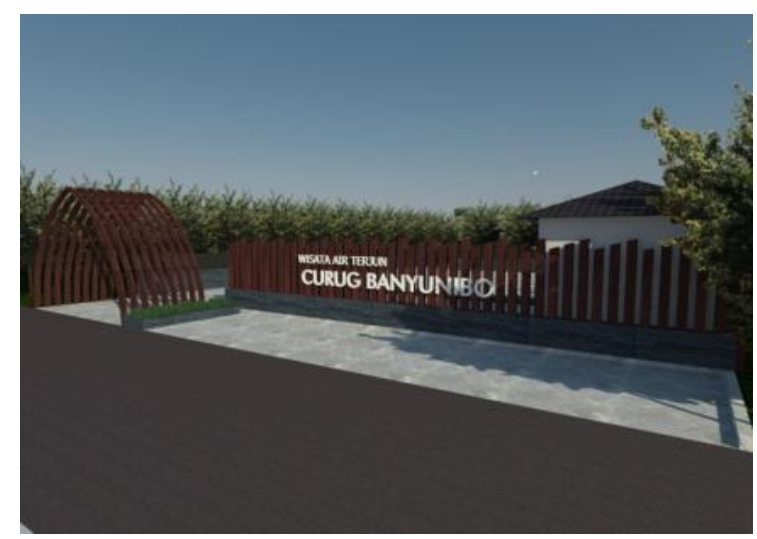

Gambar 9. Konsep bentuk gerbang masuk kawaan mengadopsi material bambu .Sumber: Gambar oleh Akbar (2019)
Dari proses analisis bentukdan dilanjutkan penggambaran dengan program SketchUp berikut adalah disain gerbang masuk kawasan Curug Banyu Nibo. Permukaan jalan masuk kawasan berupa conblock. Penataan jalan mengikuti standar jalan yang ditetapkan oleh kantor Pekerjaan Umum dan penambahan vegetasi untuk menambah estetika.

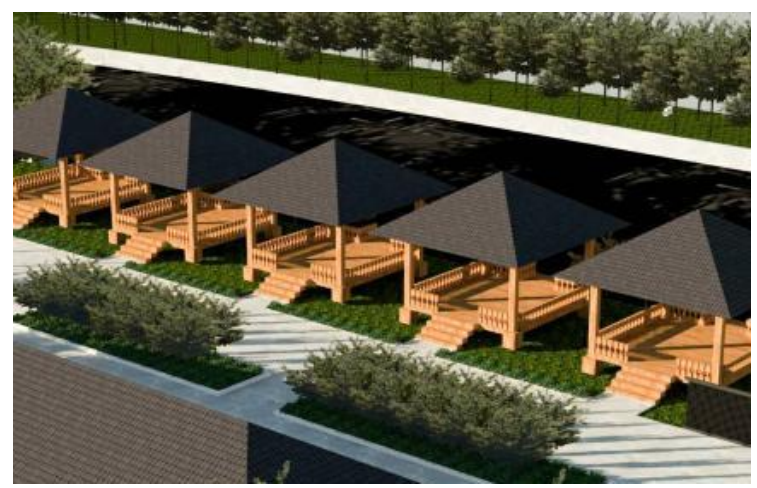

Gambar 10. Perspektif Disain Gazebo dan Jalan. Sumber: Gambar oleh Akbar (2019)

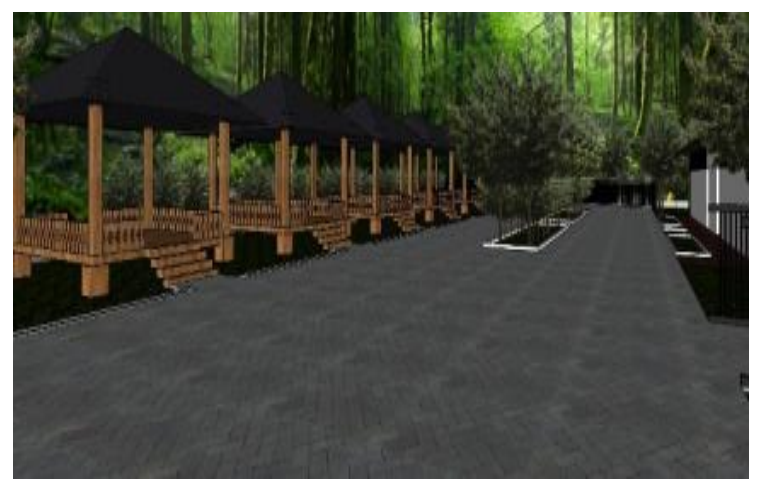

Gambar 11. Perspektif Disain Gazebo dan Jalan. Sumber: Gambar oleh Akbar (2019)

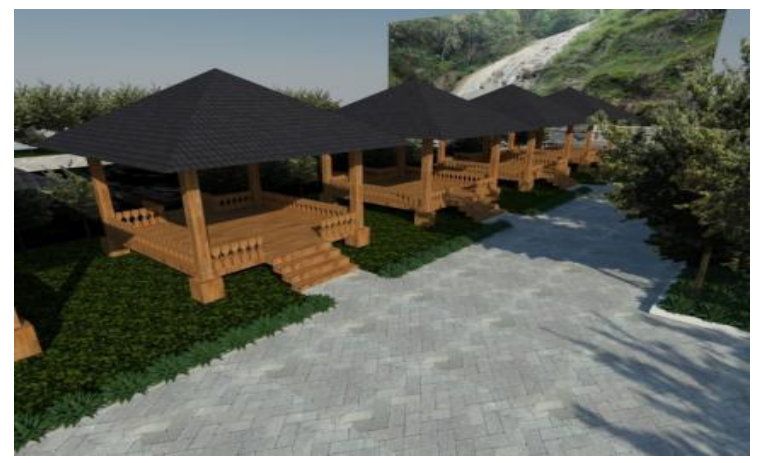

Gambar 12. Perspektif Disain Gazebo dan Jalan. Sumber: Gambar oleh Akbar (2019) 


\section{B. Ruang Parkir}

Perancangan ruang parkir mengikuti standar parker. Ukuran tiap unit kendaraan mobil $3 \mathrm{mx} 5 \mathrm{~m}$. Ruang parkir diberi tanaman peneduh mengacu Keputusan Direktur Jenderal Perhubungan Darat Nomor: 272/Hk.105/Drjd/96 tentang Pedoman Teknis Penyelenggaraan Fasilitas Parkir[9].

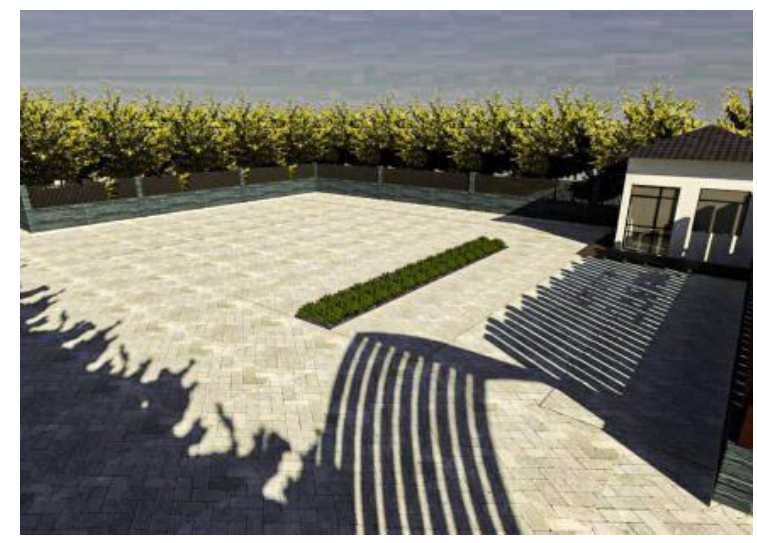

Gambar 13. Area Parkir. Sumber: Gambar oleh Akbar(2019)

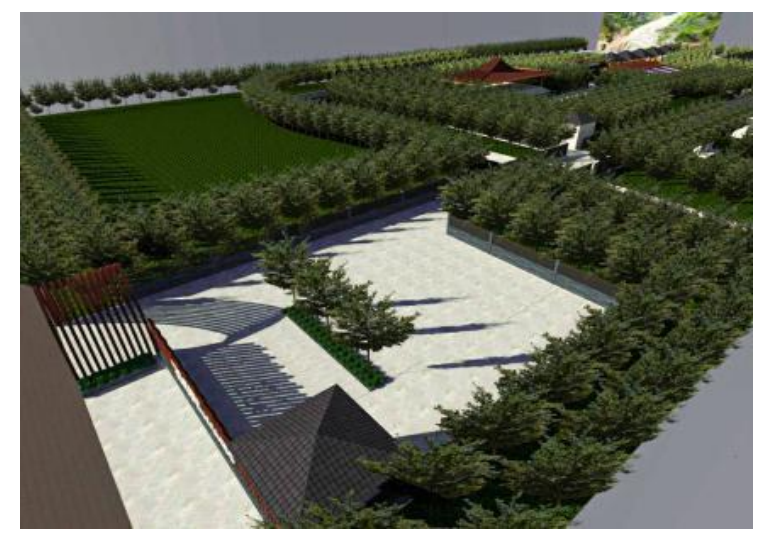

Gambar 14. Area Parkir. Sumber: Gambar oleh Akbar(2019)

\section{Tata Hijau dan Garden Furniture}

Tata hijau dan fasilitas perabot taman dirancang berdasarkan standar Peraturan Menteri PU no 6 tahun 2007. Perabot taman dan tata hijau meliputi lampu penerangan taman dan jalan, tempat dudukduduk, papan petunjuk jalan/informasi dan rambu lain yang memberikan keterangan dan fasilitas bagi pemakai jalan menurut Ditjen Binamarga dan Direktorat Pembinaan Jalan Kota No.01/P/BNKT/1991 [10].

Material tempat duduk taman selain mempertimbangkan kenyamanan juga aspek perawatan, tahan lama dan mencegah kemungkinan perusakan. Peletakan tempat duduk mempertimbangkan pemandangan (view) yang bagus, serta teduh dan tenang. Pendhapa disediakan sebagai ruang pertemuan yang besifat semi terbuka untuk mewadahi kegiatan komunal.

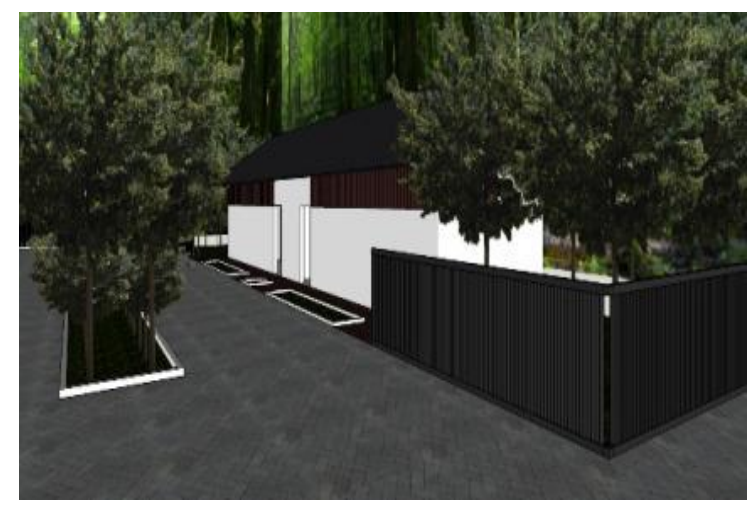

Gambar15. Tampak Perspektif Toilet. Sumber: Gambar oleh Akbar (2019)

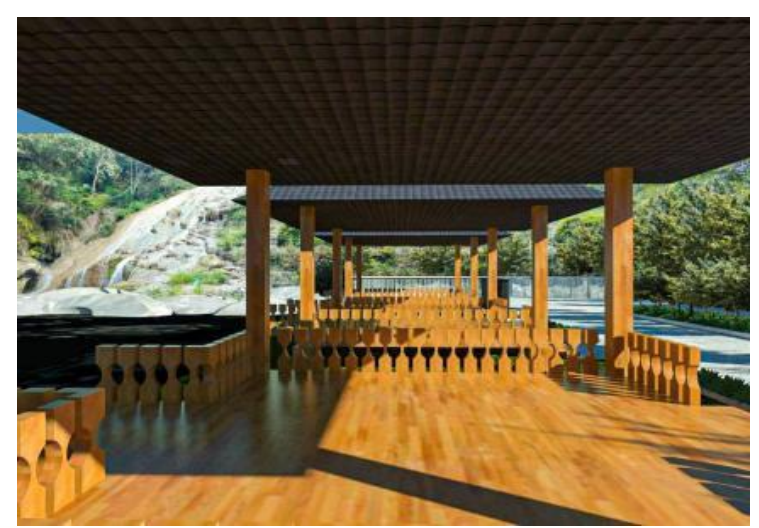

Gambar 16.Area duduk/makan. Sumber: Gambar oleh Akbar (2019) 


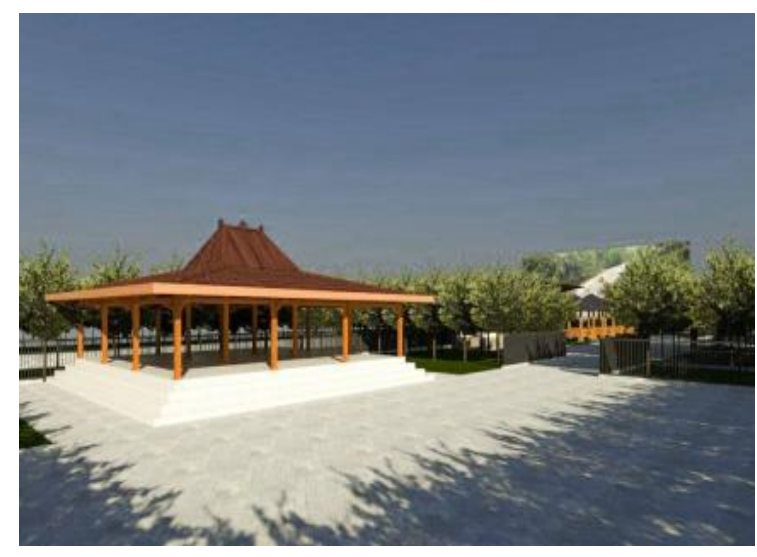

Gambar 17.Pendhapa. Sumber: Gambar oleh Akbar (2019)

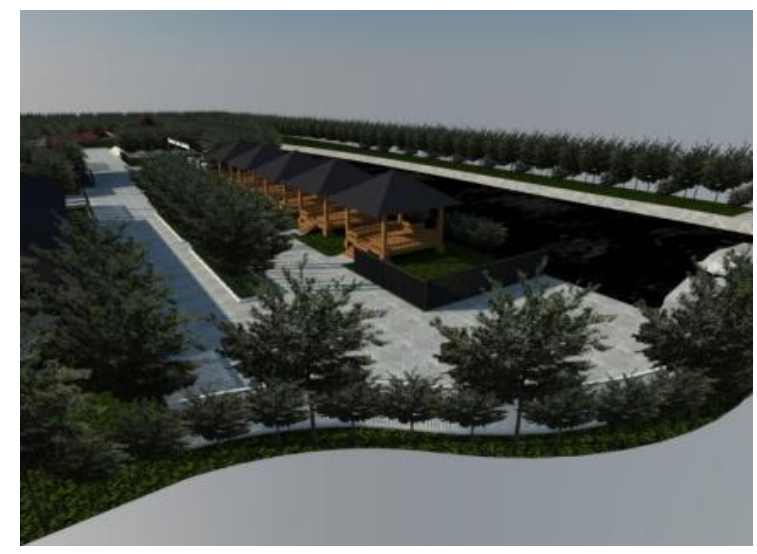

Gambar 18. Perspektifdari atas. Sumber: Gambar oleh Akbar (2019)

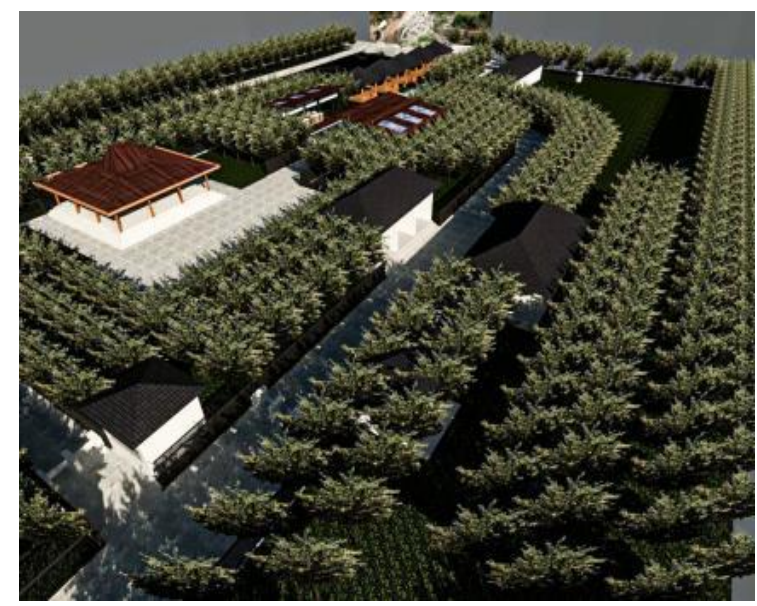

Gambar 19. Perspektifdari atas. Sumber:

Gambar oleh Akbar (2019)

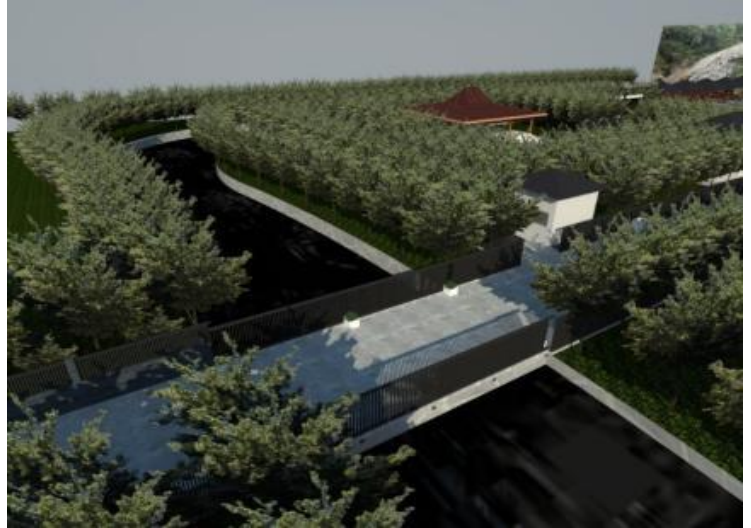

Gambar 20. Perspektifdari atas. Sumber: Gambar oleh Akbar (2019

\section{KESIMPULAN}

Kawasan Curug Banyu Nibo membutuhkan Master plan fasilitas pendukung bagi kegiatan pengunjung dengan penataan yang bertumpu pada kekuatan tapak berupa panorama alam air terjun. Disain fasilitas pendukung melibatkan peran warga sebagai pengelola aktif kawasan Curug Banyu Nibo. Komitmen masyarakat sangat baik dengan upaya yang sudah dilakukan berupa penyediaan fasilitas penunjang secara swadaya. Kesadaran dan respon warga terhadap potensi wisata Curug Banyu Nibo akan memberi manfaat peningkatan kesejahteraan melalui keterlibatan masyarakat dalam kepengelolaan potensi wisata ini. Perancangan master plan wisata alam Curug Banyu Nibo tidak mengubah bentang alam. Abdimas ini selain membantu membuat masterplan juga mendorong peran serta masyarakat khususnya dalam penyediaan faslitas dan atraksi dengan difasilitasi dokumen penataan kawasan.Kawasan wisata Curug Banyu Nibo diharapkan akan berkembang sebagai destinasi wisata alam yang menarik dan berkelanjutan. 


\section{UCAPAN TERIMA KASIH}

Ucapan terima kasih diberikan pada: 1)LPPM Universitas Atma Jaya Yogyakarta, 2) BAPPEDA Kabupaten Bantul yang telah mendukung kegiatan Abdimas.

\section{DAFTAR PUSTAKA}

[1] T. D. Oonowska M., Toward a Sustainable Tourism. In: Mariani M.M., Czakon W., Buhalis D., Vitouladiti O. (eds) Tourism Management, Marketing, and Development, New York: Palgrave Macmillan, 2016.

[2] M. J. Kuenzi C., Nature-Based Tourism. In: Renn O., Walker K.D. (eds) Global Risk Governance. International Risk Governance Council Bookseries,, Dordrecht: SpringeR, 2008.

[3] B. P. Statistik, Kecamatan Pajangan Dalam Angka 2017, Yogyakarta: BPS, 2018.

[4] U. RI, Tentang Kepariwisataan, Indonesia, Nomor 10 Tahun 2009.

[5] Fandeli, C., Dasar-Dasar Manajemen Kepariwisataan Alam, Yogyakarta, 2001.
[6] U.-u. R. Indonesia, No.5 tahun 1990 tentang Konservasi sumber daya alam hayati dan ekosistemnya, Indonesia, 1990.

[7] D. P. Umum, Rencana Detil Tata Ruang dan Zonasi Kecamatan Pajangan, Yogyakarta, 2014.

[8] K. Jatiningrat, Arti dan Simbol Kraton Yogyakarta, Yogyakarta: Tepas Kraton Yogyakarta, 2009.

[9] K. D. J. P. Darat, Pedoman Teknis Penyelenggaraan Fasilitas Parkir, Indonesia, 272/Hk.105/Drjd/96.

[10] D. B. d. D. P. J. Kota, Tentang Papan Penunjuk Jalan dan Informasi, Indonesia, No.01/P/BNKT/1991. 